\title{
Rancang Bangun Aplikasi Chat pada Platform Android dengan Media Input berupa Canvas dan Shareable Canvas untuk Bekerja Dalam Satu Canvas secara Online
}

\author{
Luffi Aditya Sandy, Rizky Januar,dan Ridho Rahman Hariadi \\ Departemen Teknik Informatika, Fakultas Teknologi Informasi Institut Teknologi Sepuluh Nopember (ITS) \\ E-mail: rizky@if.its.ac.id
}

\begin{abstract}
Abstrak-Aplikasi chat yang sudah ada umumnya menggunakan keyboard sebagai media input dari pengguna untuk mengirim pesan teks dan masih belum memberikan pengalaman yang lebih kepada pengguna dalam melakukan interaksi. Android menyediakan sebuah library untuk menampilkan media lukis layaknya sebuah kanvas yaitu Android Graphics Library yang pemanfaatannya saat ini hanya sebatas pembuatan aplikasi menggambar seperti di kanvas. Menggunakan library ini, penulis bermaksud memberikan pengalaman baru kepada pengguna dengan mengembangkan sebuah aplikasi yang memiliki fitur mengirim pesan dengan media input berupa kanvas dan membagikan kanvas ke pengguna lain sehingga kedua kanvas pengguna tersinkronisasi secara realtime dengan dukungan Firebase sebagai back-end services.
\end{abstract}

Kata Kunci-Android Graphics, Chat, Firebase, Keyboard, Library.

\section{PENDAHULUAN}

$\mathrm{M}$ EMASUKI era teknologi saat ini, kebutuhan akan fasilitas penyebaran media informasi yang cepat dan mudah semakin meningkat terutama pada aplikasi Android. Salah satu fasilitas media komunikasi sekaligus tempat bertukarnya informasi yang paling populer dan paling banyak digunakan masyarakat adalah chat. Pertukaran informasi dalam fasilitas chat saat ini tidak hanya berupa data teks, akan tetapi pengguna juga bisa mengirimkan berkas berupa video, gambar, audio, atau jenis berkas lainnya.

Kebanyakan dari aplikasi chat yang telah bermunculan menggunakan keyboard sebagai media untuk input data yang akan dikirimkan kepada lawan chat. Pada penelitian ini ditawarkan sebuah media lain yang disediakan oleh salah satu library yang terdapat dalam pemrograman Java untuk aplikasi Android yaitu kanvas. Kanvas menangani proses gambar yang didapat dari gerak sentuhan layar pada perangkat telepon pintar. Hasil menggambar di kanvas inilah yang saling dikirim antar pengguna sebagai sumber informasi atau data. Dengan adanya aplikasi ini, pengguna bisa merasakan pengalaman baru dalam melakukan percakapan online dengan lawan chat.

Selain itu, untuk membuat aplikasi menjadi lebih menarik, disediakan juga fasilitas untuk berbagi kanvas dengan lawan chat sehingga dua pengguna bisa bekerja dalam satu kanvas yang terhubung secara real time. Hal ini akan membuat aplikasi menjadi lebih interaktif dan menyenangkan.

\section{TINJAUAN PUSTAKA}

\section{A. Aplikasi Chat Serupa}

Beberapa aplikasi dengan layanan chat telah tersebar di kalangan pengguna smartphone, antara lain Line, Messenger, WhatsApp. Selain itu, juga terdapat sebuah aplikasi yang telah mengimplementasikan fitur berbagi kanvas antar pengguna. Nama aplikasi ini adalah FiveTalk. Aplikasi ini merupakan aplikasi yang sudah sangat berkembang. Namun, aplikasi ini masih memiliki error dalam penggunaannya. Aplikasi ini juga memerlukan usaha lebih dari pengguna dalam pendaftaran akun. Pengguna harus memasukkan ID secara manual sejumlah 20 karakter yang digunakan sebagai nilai unik yang berbeda antar pengguna. Pada kanvas yang disediakan juga belum terdapat fitur penambahan bentuk dua dimensi seperti persegi, lingkaran, atau garis.

\section{B. Firebase}

Adalah Backend as a Service (BaaS) yang saat ini dimiliki oleh Google. Firebase merupakaan solusi yang ditawarkan oleh Google untuk mempermudah pengembangan aplikasi mobile [1]. Dua fitur menarik dari Firebase adalah Firebase Remote Config dan Firebase Real Time Database. Selain itu juga terdapat fitur pendukung untuk aplikasi yang memerlukan push notification yaitu Firebase Notification Console.

Firebase Database merupakan penyimpanan basis data nonSQL yang memungkinan untuk menyimpan beberapa tipe data. Tipe data itu antara lain String, Long, dan Boolean. Data pada Firebase Database disimpan sebagai objek JSON tree. Tidak seperti basis data SQL, tidak ada tabel dan baris pada basis data non-SQL. Ketika ada penambahan data, data tersebut akan menjadi node pada struktur JSON. Node merupakaan simpul yang berisi data dan bisa memiliki cabang-cabang berupa node lainnya yang berisi data pula. Proses pengisian suatu data ke Firebase Database dikenal dengan istilah push.

Selain Firebase Database, Firebase menyediakan beberapa layanan lainnya yang juga dimanfaatkan dalam pengembangan aplikasi ini. Layanan tersebut antara lain Firebase Authentication, Storage, dan Cloud Messaging. Pada 
pengembangan aplikasi, layanan lainnya yang digunakan pada pengembangan aplikasi adalah Firebase Storage. Layaknya sebuah penyimpanan awan, Firebase Storage memungkin pengembang untuk mengunggah atau mengunduh sebuah berkas. Pada pengembangan aplikasi,

\section{Android Graphics Library}

Framework Android menyediakan sekumpulan fungsi untuk menggambar bentuk dua dimensi[2]. Library ini memungkinkan programmer untuk membuat grafik kedalam kanvas atau memodifikasi tampilan yang sudah ada. Kanvas adalah antarmuka untuk menuju ke layer tempat grafis sebenarnya digambarkan. Melalui kanvas, gambar secara aktual ditunjukkan dalam sebuah bitmap dasar yang ditempatkan dalam suatu jendela.

\section{Realm}

Adalah sebuah alternatif penyimpanan data pada yang bisa menggantikan SQLite sebagai penyimpanan data bawaan pada Android. Realm melakukan penyimpanan dengan berorientasi pada objek (native objects). Tidak perlu melakukan penyalinan objek dari penyimpanan basis data, memodifikasi, dan menyimpannya lagi karena pengembang bekerja dalam objek yang sesungguhnya. Setiap objek tersinkronisasi pada setiap aktivitas yang dilakukan pada objek tersebut dan data dalam objek akan selalu tersimpan pada aplikasi[3].

\section{DESAIN SISTEM}

\section{A. Perancangan Arsitektur}

Pada arsitektur aplikasi, digambarkan dependensi aplikasi terhadap komponen-komponen di luar aplikasi yang digolongkan ke dalam dua kelompok komponen yaitu services dan library. Services adalah layanan-layanan yang digunakan aplikasi dalam mendukung penyimpanan atau pengiriman data baik lokal maupun antar perangkat, sedangkan library adalah kumpulan fungsi untuk memudahkan implementasi program. Arsitektur ini dapat dilihat pada Gambar 1.

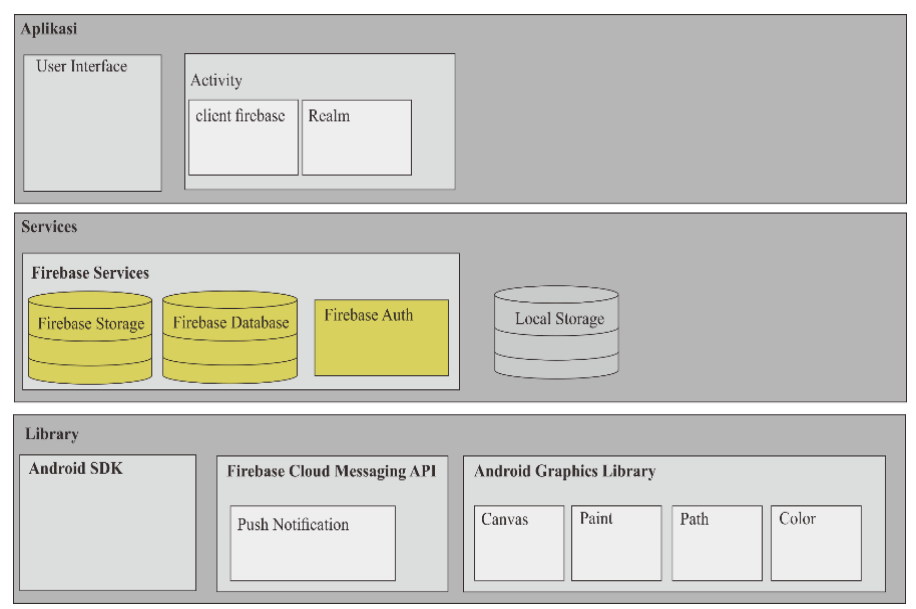

Gambar 1. Arsitektur Sistem

\section{B. Perancangan Alur Kasus Penggunaan}

Pada perancangan ini dijelaskan alur penggunaan aplikasi oleh pengguna seperti pada Gambar 1 sehingga dapat digunakan sebagai acuan untuk membuat antarmuka aplikasi. Secara umum, pengguna bisa melakukan dua fungsi utama yaitu melakukan chat menggunakan kanvas dan membagi kanvas dengan pengguna lain.

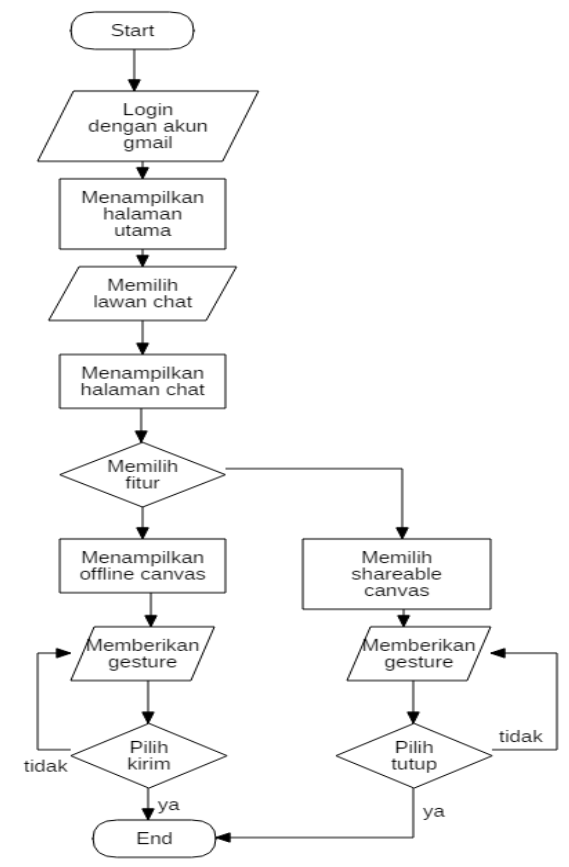

Gambar 2. Diagram Alir Penggunaan Aplikasi

\section{Perancangan Alur Pemrosesan Data}

Perancangan alur pemrosesan data menjelaskan cara sistem dalam memproses data sehingga bisa ditampilkan ke pengguna sesuai fungsinya. Pada alur pemrosesan data dibagi menjadi beberapa bagian yaitu pengolahan, penyimpanan, perpindahan, dan pengiriman data pada sistem.

1) Alur Pengolahan Data Sentuhan pada Kanvas

Alur pengolahan data kanvas berisi langkah-langkah aplikasi dalam menerima sentuhan dan menggambarkan sentuhan tersebut ke dalam kanvas yang ditampilkan ke pengguna.

a. Aplikasi menyediakan suatu fungsi yang menangani setiap sentuhan yang diterima kanvas. Sentuhan dibagi menjadi tiga jenis yaitu sentuhan awal saat pengguna pertama kali memberi sentuhan, melakukan perpindahan sentuhan, dan saat pengguna melepas sentuhan pada kanvas.

b. Aplikasi menyediakan suatu variabel yang disebut path untuk menyimpan satu grafis mulai dari pengguna menyentuh hingga melepas sentuhan.

c. Ketika satu jenis sentuhan diterima, aplikasi melakukan pengecekan jenis gambar yang dipilih pengguna. Jenis gambar dibagi menjadi beberapa bentuk yaitu persegi, lingkaran, garis, dan abstrak (freehand).

d. Saat pengguna melepas sentuhan dari kanvas, path menggambar bentuk yang dipilih pengguna ke dalam 
kanvas dengan titik-titik koordinat yang direkam selama sentuhan berlangsung.

2) Alur Penyimpanan Data pada Offline Canvas

Alur penyimpanan data pada offline canvas melalui beberapa tahapan sebagai berikut:

a. Aplikasi menyediakan suatu penyimpanan yang berisi daftar path yang disebut canvas path.

b. Setiap pengguna melepaskan sentuhan, maka canvas path menyimpan path tersebut pada urutan terakhir.

Langkah pertama sampai kedua diulang setiap pengguna mulai memberikan gesture atau menyentuh layar pada kanvas lagi.

3) Alur Perpindahan Data pada Fitur Undo dan Redo Offline Canvas

Alur penyimpanan data pada fitur undo dan redo offline canvas melalui beberapa tahapan untuk setiap satu kali prosesnya. Tahapan-tahapan pada satu kali penggunaan fitur undo adalah sebagai berikut:

a. Membuat sebuah variabel yang berisi daftar path yang disebut redo path untuk menyimpan path yang dibatalkan oleh pengguna.

b. Melakukan pengecekan pada canvas path. Jika kosong, maka fitur undo tidak bisa digunakan.

c. Jika canvas path tidak kosong, maka path terakhir pada canvas path akan dipindahkan ke dalam redo path.

Setiap pengguna memberikan sebuah gesture, maka semua path pada redo path akan dihapus. Selanjutnya tahapantahapan pada satu kali penggunaan fitur redo adalah sebagai berikut :

a. Melakukan pengecekan pada redo path. Jika kosong, maka fitur tidak bisa digunakan.

b. Jika redo path tidak kosong, maka path terakhir pada redo path akan dipindahkan ke urutah terakhir dalam canvas path.

Kemudian canvas akan menggambar ulang setiap path yang ada dalam canvas path sesuai dengan urutan masuk

4) Alur Penyimpanan Data pada Berbagi Kanvas

Alur penyimpanan data pada berbagi kanvas melalui beberapa tahapan sebagai berikut:

a. Aplikasi menyediakan sebuah global path yang menyimpan daftar dari semua path yang dibuat oleh kedua pengguna dan sebuah canvas path untuk menyimpan semua path milik masing-masing pengguna.

b. Ketika pengguna melepaskan sentuhan dan disimpan kedalam sebuah path, maka path tersebut akan disimpan di urutan terakhir pada dua daftar path yaitu global path dan canvas path milik pengguna tersebut.

Shareable canvas pada pengguna akan menggambar ulang setiap ada penambahan path di global path.

5) Alur Perpindahan Data Undo dan Redo pada Shareable Canvas

Alur penyimpanan data pada berbagi kanvas melalui beberapa tahapan sebagai berikut: a. Aplikasi menyediakan sebuah global path yang menyimpan daftar dari semua path yang dibuat oleh kedua pengguna dan sebuah canvas path untuk menyimpan semua path milik masing-masing pengguna.

b. Ketika pengguna melepaskan sentuhan dan disimpan kedalam sebuah path, maka path tersebut akan disimpan di urutan terakhir pada dua daftar path yaitu global path dan canvas path milik pengguna tersebut.

Shareable canvas pada pengguna akan menggambar ulang setiap ada penambahan path di global path.

\section{Perancangan Basis Data}

Perancangan basis data digunakan untuk menyusun struktur data sistem pada penelitian ini dengan mengimplementasikan Firebase Database sebagai media penyimpanan data. Firebase Database merupakan basis data non-SQL sehingga tidak memerlukan aturan tertentu untuk mengatur struktur basis data. Oleh karena itu, rancangan basis data pada Firebase Database disimpan dalam format objek JSON tree yang tidak memiliki tabel atau baris seperti data SQL. Pada JSON tree dikenal dengan istilah node untuk setiap proses memasukkan data ke Firebase Database.

\section{UJI COBA APLIKASI}

Terdapat beberapa metode yang dapat digunakan untuk melakukan pengujian terhadap perangkat lunak. Pada pengerjaan aplikasi ini, digunakan pengujian dengan metode White-Box dan Black-Box.

Metode White-Box adalah pengujian dengan meneliti kodekode pada aplikasi dan menganalisis kesalahan yang terdeteksi. Metode Black-Box adalah pengujian terhadap fungsionalitas dari perangkat lunak. Metode Grey-Box adalah metode pengujian perangkat lunak yang mengombinasikan antara metode Black-Box dan White-Box. Metode Grey-Box berusaha mengambil kelebihan dari kedua metode tersebut dan mengurangi kekurangan keduanya.

\section{A. Pengujian Fungsionalitas}

Pengujian fungsionalitas dilakukan dengan menyiapkan beberapa skenario pengujian sebagai tolak ukur keberhasilan pengujian dan mengacu pada fungsionalitas aplikasi. Metode pengujian yang digunakan pada pengujian fungsionalitas mengacu pada metode White-Box dan Black-Box.

\section{B. Pengujian Aplikasi terhadap Pengguna}

Pengujian perlu dilakukan oleh pengguna secara langsung sehingga bisa mengetahui bahwa aplikasi telah memenuhi tujuan aplikasi atau belum, yaitu memberi pengalaman baru dalam berinteraksi dengan pengguna lain. Pengujian juga dilakukan untuk mengetahui bahwa fitur utama aplikasi telah berjalan sesuai dengan rancangan. Fitur utama yang diuji oleh pengguna pada bagian ini adalah pengiriman gambar sebagai hasil konversi dari kanvas yang pengguna buat dan membagi kanvas dengan pengguna lain sehingga bisa bekerja dalam satu kanvas yang terhubung. Hasil kuisioner untuk dua fitur dapat dilihat pada Tabel 1 dan Tabel 2. 
Tabel 1.

Hasil Kuisioner Fitur Mengirim Pesan

\begin{tabular}{clc}
\hline \hline No & \multicolumn{1}{c}{ Pertanyaan } & Nilai \\
\hline 1 & $\begin{array}{l}\text { Apakah pesan gambar/teks yang dikirim oleh } \\
\text { pengguna lain kepada anda dapat diterima dengan } \\
\text { baik? }\end{array}$ & 4,0 \\
2 & $\begin{array}{l}\text { Apakah tampilan aplikasi mempermudah dan } \\
\text { membuat anda nyaman dalam menggunakan aplikasi? }\end{array}$ & 3,5 \\
3 & $\begin{array}{l}\text { Apakah aplikasi memberikan pengalaman baru dalam } \\
\text { melakukan chat? }\end{array}$ & 3,7 \\
\hline \hline
\end{tabular}

Tabel 2.

Hasil Kuisioner Fitur Berbagi Kanvas

\begin{tabular}{clc}
\hline \hline No & \multicolumn{1}{c}{ Pertanyaan } & Nilai \\
\hline 1 & $\begin{array}{l}\text { Apakah aplikasi menghubungkan kanvas milik anda } \\
\text { dengan pengguna lain? }\end{array}$ & 3,9 \\
2 & $\begin{array}{l}\text { Apakah kanvas secara cepat diperbarui ketika } \\
\text { pengguna lain yang terhubung membuat suatu } \\
\text { gambar/goresan? }\end{array}$ & 3,3 \\
3 & $\begin{array}{l}\text { Apakah tampilan aplikasi mempermudah anda dalam } \\
\text { menggunakan fitur "share canvas"? }\end{array}$ & 3,0 \\
& $\begin{array}{l}\text { Apakah aplikasi memberikan pengalaman baru } \\
\text { kepada anda dalam berinteraksi kepada pengguna? }\end{array}$ & 3,5 \\
\hline \hline
\end{tabular}

\section{KESIMPULAN}

Berdasarkan pengujian fungsionalitas yang dilakukan, dapat semua pengujian menunjukkan nilai keberhasilan. Oleh karena itu dapat disimpulkan bahwa aplikasi sudah memenuhi semua fungsionalitas yang diharapkan. Selain itu, Pengujian yang dilakukan terhadap pengguna menghasilkan kesimpulan dalam berupa rata-rata yang menunjukkan persetujuan pengguna terhadap kesesuaian, kemudahan, dan ketertarikan fitur yang disediakan aplikasi.

Berdasarkan Tabel 1 dan Tabel 2, dapat diketahui bahwa nilai rata-rata hasil kuesioner adalah 3,557 . Nilai rata-rata yang telah melebihi angka 3 atau memiliki arti "setuju" menunjukkan bahwa aplikasi sudah nyaman dan mudah digunakan serta fitur pada aplikasi telah memberikan pengalaman baru kepada pengguna dalam berinteraksi dengan pengguna lain.

\section{DAFTAR PUSTAKA}

[1] B. Octavianus, [Android] Apa itu Firebase ? 2016.

[2] Developer.android.com, "Canvas and Drawables | Android Developers," developer.android.com, 2016. [Online]. Available: https://developer.android.com/guide/topics/graphics/2dgraphics.html.

[3] Realm.io, "Realm Mobile Platform Overview," realm.io, 2017. [Online]. Available: https://realm.io/docs/get-started/overview. 